\title{
Resposta morfogênica de embriões zigóticos de Erythrina velutina Willd. (Leguminosae) cultivados in vitro
}

\author{
Priscila Tavares Fonseca ${ }^{1}$, Cristina Ferreira Nepomuceno ${ }^{2}$, Bruno Freitas Matos Alvim³, \\ José Raniere Ferreira de Santana \\ http://dx.doi.org/10.1590/0034-737X201461050002
}

\section{RESUMO}

O cultivo in vitro de embriões zigóticos é uma técnica promissora para se avançar no estudo do desenvolvimento embrionário e da quebra da dormência de sementes. Diante do exposto, objetivou-se, com este trabalho, avaliar o efeito dos reguladores vegetais 6-benzilaminopurina (BAP) e ácido naftalenoacético (ANA) no potencial morfogenético, in vitro, de embriões zigóticos de mulungu. Embriões zigóticos maduros, oriundos de sementes foram utilizados inteiros, ou seccionados em plúmula, região intermediária e radícula, sendo posteriormente inoculados em meio de cultura WPM, suplementado com combinações de BAP $(0,0 ; 2,0 ; 4,0 ; 8,0 ; 12,0$ e $16,0 \mu \mathrm{M})$ e ANA $(0,0 ; 1,0$ e 2,0 $\mu \mathrm{M})$, acrescido de $87,64 \mathrm{mM}$ de sacarose e solidificado com 0,7\% de ágar. Após 30 dias, avaliaram-se a percentagem de regeneração dos embriões e ápice plumular, o número de brotos, o número de folhas, o comprimento da parte aérea dos brotos, o número de raízes e a percentagem de formação de calos oriundos da região intermediária e da radícula. É possível a regeneração in vitro de mulungu, a partir dos explantes plúmula e embriões zigóticos inteiros, cultivados em meio de cultura WPM, suplementado com 4,0 $\mu$ M de BAP. Regiões intermediárias e da radícula promoveram a formação de calos compactos $(96,06 \%)$, na combinação de $10,63 \mu \mathrm{M}$ BAP e $2,0 \mu \mathrm{M}$ de ANA.

Palavras-chave: mulungu, 6-benzilaminopurina, ácido naftalenoacético, morfogênese.

\section{ABSTRACT \\ Morphogenic response of zygotic embryos of Erythrina velutina Willd. (Leguminosae) cultivated in vitro}

The in vitro culture of zygotic embryos represents a promising technique to study the embryonic development and dormancy in seeds. The objective of this study was to determine the effect of plant growth regulators, 6benzylaminopurine (BAP) and naphthalene acetic (NAA), in the morphogenetic potential of in vitro zygotic embryos of mulungu. Mature zygotic embryos from seeds were either used as a whole or sectioned in plumule, radicle and intermediate region, and subsequently inoculated in WPM medium supplemented with combinations of BAP (0.0, 2.0, 4, 0, 8.0, 12.0 and $16.0 \mu \mathrm{M})$ and NAA $(0.0,1.0$ and $2.0 \mu \mathrm{M})$, added with $87.65 \mathrm{mM}$ sucrose and $0.7 \%$ agar. After 30 days, the following parameters were evaluated: regeneration percentage of embryos and plumularapice, number

Recebido para publicação em 22/11/2012 e aprovado em 06/02/2014

Parte da Dissertação de Mestrado da primeira autora.

'Bióloga, Mestre. Laboratório de Cultura de Tecidos Vegetais, Universidade Estadual Feira de Santana, Caixa Postal 252-294, 44031-460, Feira de Santana, Bahia, Brasil. pristavares25@hotmail.com (autora para correspondência).

${ }^{2}$ Bióloga, Doutora. Laboratório de Cultura de Tecidos Vegetais, Universidade Estadual Feira de Santana, Caixa Postal 252-294, 44031-460, Feira de Santana, Bahia, Brasil. nepomucenocf@yahoo.com.br

${ }^{3}$ Biólogo, Mestre. Laboratório de Cultura de Tecidos Vegetais, Universidade Estadual Feira de Santana, Caixa Postal 252-294, 44031-460, Feira de Santana, Bahia, Brasil. brunoalvim18@hotmail.com

${ }^{4}$ Engenheiro-Agrônomo, Doutor. Laboratório de Cultura de Tecidos Vegetais, Universidade Estadual Feira de Santana, Caixa Postal 252-294, 44031-460, Feira de Santana, Bahia, Brasil. raniere@uefs.br 
of buds, number of leaves, aerial part length of buds, number of roots and percentage of callifrom the intermediate region and radicle. It was feasible the in vitro regeneration of mulungu from plumule explant and whole zygotic embryos in WPM medium supplemented with $4.0 \mu \mathrm{M}$ BAP. Moreover, intermediate and radicle regions promoted the formation of compact calli $(96.06 \%)$ by combining $10.63 \mu \mathrm{M}$ BAP and $2.0 \mu \mathrm{M}$ NAA.

Key words: 6-benzylaminopurine, morphogenesis, mulungu, naphthalene acetic.

\section{INTRODUÇÃO}

O mulungu (E. velutina) é uma espécie lenhosa, distribuída na Caatinga e nas florestas secas do oeste da América do Sul, no Peru, Equador e Caribe (Costa norte da Venezuela e Cuba). É nativo do bioma Caatinga, ocorrendo desde a Paraíba e Piauí até o norte de Minas Gerais (Queiroz, 2009). Espécies lenhosas como mulungu, geralmente, quando micropropagadas, apresentam baixa taxa de multiplicação, conforme relatado por Costa et al. (2010), sendo necessário aprofundar o conhecimento sobre o seu potencial morfogênico.

A morfogênese das plantas é consequência da integração dos processos de divisão e de diferenciação celular (Handro \& Floh, 1990). Esses processos são controlados por uma variedade de sinais internos ou do ambiente, como os hormônios e a luz, capazes de modificar o crescimento e o desenvolvimento. Segundo George \& Sherrington (1984), o crescimento e a morfogênese in vitro são fatores regulados pela interação e balanço dos reguladores de crescimento vegetal existentes no meio de cultura, principalmente citocininas e auxinas.

Alguns padrões morfogênicos são frequentemente relatados, como: a neoformação de raízes e gemas caulinares, em murmuru - Astrocaryum ule (Pereira et al., 2006), Annona glabra L. (Santana et al., 2008), pistachio - Pistacia vera L. (Benmahioul et al., 2009); a formação de calos e embriões somáticos em canafístulaPeltophorum dubium (Bassan et al., 2006), Heliconia bihai (L.) L. cv. Lobster Claw Two (Ulisses et al., 2011) e em maracujá - Passiflora edulis Sims (Pinto et al., 2012), estando intimamente ligados aos fatores supracitados, bem como às condições de cultivo e ao tipo de explante utilizado.

Por essas razões, torna-se importante a avaliação do potencial morfogênico de embriões zigóticos de $E$. velutina, uma vez que são excelentes explantes para propagação clonal in vitro, por sua natureza juvenil e seu alto potencial regenerativo (Hu \& Ferreira, 1998). O emprego de embriões zigóticos pode contribuir para superação de barreiras genéticas à germinação, produção de plantas assépticas, elucidação de aspectos inerentes à nutrição do embrião no óvulo (Hu \& Ferreira,
1998), bem como para observar os processos morfogenéticos in vitro, contribuindo para avançar no conhecimento da biologia da espécie em estudo.

Diante do exposto, objetivou-se com este trabalho avaliar o efeito de BAP e do ANA no potencial morfogenético in vitro de embriões zigóticos de mulungu.

\section{MATERIAL E MÉTODOS}

Os experimentos foram realizados no Laboratório de Cultura de Tecidos Vegetais (LCTV), da Unidade Experimental Horto Florestal (UNEHF), da Universidade Estadual de Feira de Santana (UEFS), localizado no município de Feira de Santana, região do Semiárido da Bahia.

Foram utilizadas sementes de E. velutina fornecidas pela EMBRAPA Semiárido em Petrolina-PE armazenadas no LCTV do Horto Florestal, sob temperatura ambiente.

Inicialmente, as sementes foram submetidas à escarificação mecânica em mini-retífica e ao processo de desinfestação, segundo metodologia de Costa et al. (2010). As sementes foram lavadas em água corrente por 10 minutos, desinfestadas por imersão em etanol, a 70\%, por 2 minutos, com posterior transferência para solução de hipoclorito de sódio - $\mathrm{NaOCl}[2,5 \%$ de cloro ativo], misturado a 2 gotas de detergente neutro, por 20 minutos. Após a desinfestação, as sementes foram lavadas 4 vezes, com água destilada estéril e, em seguida, colocadas para embebição, durante 20 horas, em recipiente com água destilada estéril, vedado com filme PVC, em câmara de fluxo laminar sob condições assépticas.

Após o período de pré-embebição, realizou-se a incisão das sementes, cortando-as transversalmente no centro, separando-se os cotilédones e utilizando-se pinça para a retirada do embrião zigótico, sob condições assépticas, em câmara de fluxo laminar.

O embrião zigótico foi utilizado intacto, ou seccionado em plúmula, região intermediária e radícula. Os explantes foram posteriormente inoculados em frascos, com $60 \mathrm{~mL}$ de meio de cultura WPM (Lloyd \& Mccown, 1980), suplementado com concentrações de 6-benzilaminopurina (BAP; 0,0; 4,0; 8,0; 12,0 e 16,0 $\mu \mathrm{M}$ ), combinado com ácido naftalenoacético (ANA; 0,0 ; 
1,0 e 2,0 $\mu \mathrm{M}$ ), suplementado com 87,64 mM de sacarose e solidificado com $0,7 \%$ de ágar. $\mathrm{O}$ pH do meio de cultura foi ajustado para 5,7 $\pm 0,1$, antes da autoclavagem, a 121 ${ }^{\circ} \mathrm{C}$ e sob pressão de $1 \mathrm{~atm}$, por 15 minutos. As culturas foram mantidas em sala de crescimento com temperatura de $25 \pm 3{ }^{\circ} \mathrm{C}$, fotoperíodo de 16 horas, umidade relativa de $60 \%$ e radiação fotossintética ativa de $60 \mu \mathrm{mol} \mathrm{m} \mathrm{m}^{-2} \mathrm{~s}^{-1}$, fornecida por lâmpadas fluorescentes branca-frias.

O delineamento experimental foi inteiramente casualizado, em arranjo fatorial 4 × 5 x 3 (tipos de explantes $\mathrm{x}$ concentrações de BAP $\mathrm{x}$ concentrações de ANA) totalizando 60 tratamentos, com 5 repetições, sendo cada frasco constituído por 4 unidades experimentais. Após 30 dias da inoculação, avaliaram-se: a percentagem de regeneração dos embriões e do ápice plumular, o número de brotos, o número de folhas, o comprimento da parte aérea dos brotos, o número de raízes e a percentagem de calos oriundos da região intermediária e da radícula.

Os dados foram submetidos à análise de variância (ANAVA) e as médias, comparadas pelo teste de Tukey, a 5\% de significância, para os fatores qualitativos, usando-se as equações de regressão polinomial para os fatores quantitativos. A análise foi realizada com o software SISVAR (Ferreira, 2011).

\section{RESULTADOS E DISCUSSÃO}

A interação BAP e tipo de explante influenciou a percentagem de regeneração (Tabela 1), observando-se que apenas os explantes embrião inteiro e ápice plumular foram responsivos para a regeneração de brotos (Tabela 2). Ao analisar esta variável, não foi possível o ajuste de um modelo matemático significativo para ambos explantes responsivos (Figura 1).

$\mathrm{Na}$ ausência de reguladores de crescimento vegetal, a percentagem de regeneração $(93,33 \%)$ foi maior para explante embrião inteiro em relação ao explante plúmula (75\%) (Tabela 2). A taxa de regeneração para o explante embrião inteiro foi mantida com a adição de reguladores de crescimento vegetal, diferentemente do reportado por Costa \& Aloufa (2007), na regeneração in vitro de embriões zigóticos de plântulas de tamareira (Phoenix dactylifera L.), em que a adição de reguladores de crescimento BAP e AIA resultaram em efeito negativo, registrando-se a maior taxa, 66,6\% de conversão de embriões zigóticos, em meio de cultura MS, isento dos reguladores de crescimento.

No entanto, ao suplementar-se o meio de cultura com BAP, verificou-se aumento na taxa de regeneração para o explante plúmula, em todas as concentrações testadas, obtendo-se um acréscimo de $23,75 \%$, quando compara-

Tabela 1. Resumo da análise de variância para porcentagem de regeneração (\%R), número de brotos (NB), número de folhas (NF), número de raízes (NR), comprimento da maior parte aérea (CPA), matéria seca da parte aérea (MSPA) e formação de calos de plantas de Erytrina velutina submetidas a concentrações de Benzilaminopurina (BAP) combinado e isolado com ácido naftaleno acético (ANA) em meio de cultura WPM

\begin{tabular}{lcccccccc}
\hline \multirow{2}{*}{ FV } & \multirow{2}{*}{ GL } & \multicolumn{7}{c}{ Quadrado médio } \\
\cline { 3 - 8 } & & $\mathbf{\%}$ & NB & NF & NR & CPA & MSPA & F.CALO \\
\hline BAP & 4 & $545,50^{* *}$ & $0,46^{* *}$ & $37,80^{* *}$ & $19,53^{* *}$ & $2492,41^{* *}$ & $381,90^{* *}$ & $21395,00^{* *}$ \\
ANA & 2 & $187,06^{\text {ns }}$ & $0,076^{\text {ns }}$ & $2,20^{\text {ns }}$ & $0,23^{\text {ns }}$ & $177,89^{\text {ns }}$ & $326,66^{* *}$ & $4330^{* *}$ \\
Explante & 1 & $168233,09^{* *}$ & $2,88^{* *}$ & $692,16^{* *}$ & $11,29^{* *}$ & $14100,67^{* *}$ & $3465,37^{* *}$ & $563,33^{\text {ns }}$ \\
BAP x ANA & 8 & $234,90^{\text {ns }}$ & $0,12^{\text {ns }}$ & $2,62^{\text {ns }}$ & $0,13^{\text {ns }}$ & $41,68^{\text {ns }}$ & $158,29^{*}$ & $630,00^{* *}$ \\
BAP x Explante & 4 & $316,92^{* *}$ & $0,05^{\text {ns }}$ & $3,05^{\text {ns }}$ & $7,92^{* *}$ & $2433,22^{* *}$ & $883,37^{* *}$ & $255,00^{\text {ns }}$ \\
ANA x Explante & 2 & $75,75^{\text {ns }}$ & $0,076^{\text {ns }}$ & $4,37^{\text {ns }}$ & $0,06^{\text {ns }}$ & $78,75^{\text {ns }}$ & $646,28^{* *}$ & $3,33^{\text {ns }}$ \\
BAP x ANA x Explante & 8 & $112,34^{\text {ns }}$ & $0,073^{\text {ns }}$ & $0,94^{\text {ns }}$ & $0,16^{\text {ns }}$ & $30,04^{\text {ns }}$ & $101,71^{\text {ns }}$ & $195,00^{\text {ns }}$ \\
Resíduo & 90 & 92,06 & 0,064 & 2,37 & 0,36 & 53,92 & 61,98 & 134,44 \\
\hline CV $(\%)$ & & 20,93 & 23,55 & 33,92 & 32,42 & 32,67 & 51,47 & 14,77 \\
\hline
\end{tabular}

** Significativo a $1 \%$ de probabilidade pelo teste $\mathrm{F}$. ${ }^{\text {NS }}$ Não significativo a $5 \%$ de probabilidade pelo teste $\mathrm{F}$.

Tabela 2. Porcentagem de regeneração (\%R) de mulungu em função de BAP aos 30 dias de inoculados em meio de cultura WPM

\begin{tabular}{lccccc}
\hline \multirow{2}{*}{ Explante } & \multicolumn{5}{c}{ BAP $(\boldsymbol{\mu M})$} \\
\cline { 2 - 6 } & $\mathbf{0}$ & $\mathbf{4}$ & $\mathbf{8}$ & $\mathbf{1 2}$ & $\mathbf{1 6}$ \\
\hline Embrião & $93,33 \mathrm{a}$ & $98,33 \mathrm{a}$ & $86,67 \mathrm{a}$ & $93,33 \mathrm{a}$ & $96,67 \mathrm{a}$ \\
Plúmula & $75,0 \mathrm{~b}$ & $98,35 \mathrm{a}$ & $83,37 \mathrm{a}$ & $93,33 \mathrm{a}$ & $98,33 \mathrm{a}$ \\
R. Intermediária & - & - & - & - & - \\
Radícula & - & - & - & - & - \\
\hline
\end{tabular}

*Médias seguidas pela mesma letra na coluna, não diferem estatisticamente entre si, a 5\% de probabilidade pelo teste de Tukey. 
do com a taxa do meio isento de regulador de crescimento vegetal (Tabela 2). O efeito da adição de reguladores de crescimento vegetal, assim como em ápice plumular de mulungu, foi significativo no cultivo de ápices plumular de turkish cowpea (Vigna unguiculata L), quando embriões zigóticos, tratados com pulso de 44,4 $\mu \mathrm{M}$ de BAP e, posteriormente, inoculados em meio para regeneração acrescido de $\operatorname{BAP}(1,11$ a $5,55 \mu \mathrm{M})$ e ANA $(0,54 \mu \mathrm{M})$, mostraram $100 \%$ de regeneração de ápices plumular (Aasim et al., 2009).

Possivelmente, a síntese, no ápice caulinar, de citocinina do explante plumular de mulungu não é suficiente para promover um balanço auxina/citocinina favorável ao crescimento da gema caulinar, o qual foi suprido com a adição de BAP ao meio de cultura. Sabe-se que o centro produtor de citocinina ocorre nos meristemas radiculares, no entanto, pode sua síntese ocorrer nos meristemas presentes no ápice caulinar (Taiz \& Zeiger, 2009).
Ao analisar a variável número de brotos, verificouse efeito isolado das fontes de variação BAP e Tipo de explante. Em função do tipo de explante, registrou-se a maior média $(1,23)$ para embrião zigótico inteiro, sendo que, para o explante plúmula, a média foi de 0,93 . Os demais explantes (região intermediária e radícula) não formaram brotos. Ao avaliar o fator isolado BAP, através da análise de regressão não foi possível o ajuste de um modelo matemático representativo, porém, foi observado em 16,0 $\mu \mathrm{M}$ de BAP maior formação de brotações (1,23 brotos/explante) (Figura 2).

A percentagem de brotos oriundos de embriões zigóticos de mulungu é considerada baixa, semelhantemente ao verificado por Dantas et al. (2002), que obtiveram 2,3 brotos por explante, quando utilizados $4 \mu \mathrm{M}$ de BAP no cultivo in vitro de embriões zigóticos de macieira M9 (Mallus pumilla). Já, para o explante plúmula da espécie em estudo, os dados divergem dos reportados por Horbach et al. (2012), que obtiveram

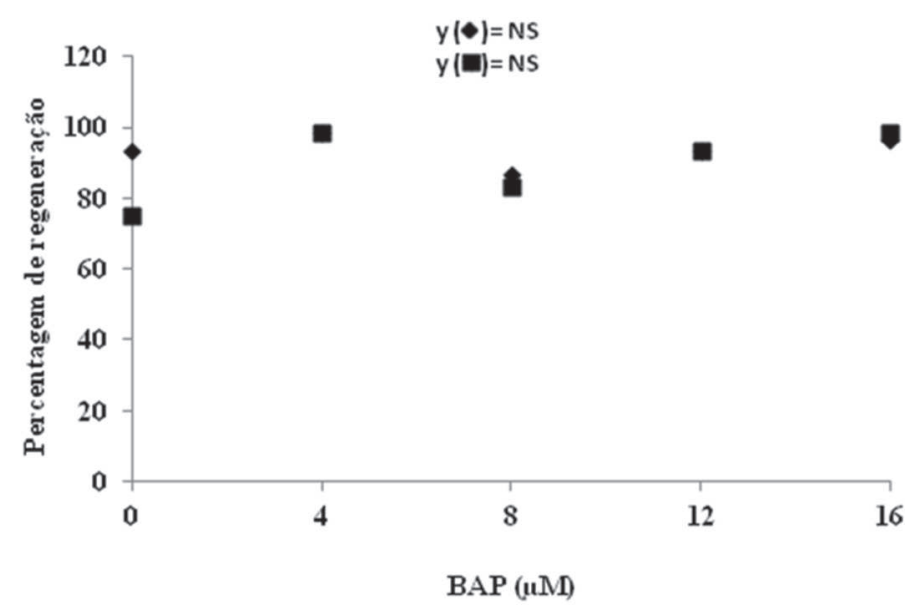

Figura 1. Percentagem de regeneração obtidos de explante de embriões zigóticos inteiro ( $\bullet$ ) e plúmula ( $\square$ ) de mulungu em função dos

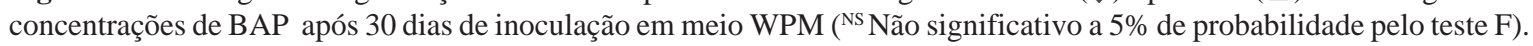

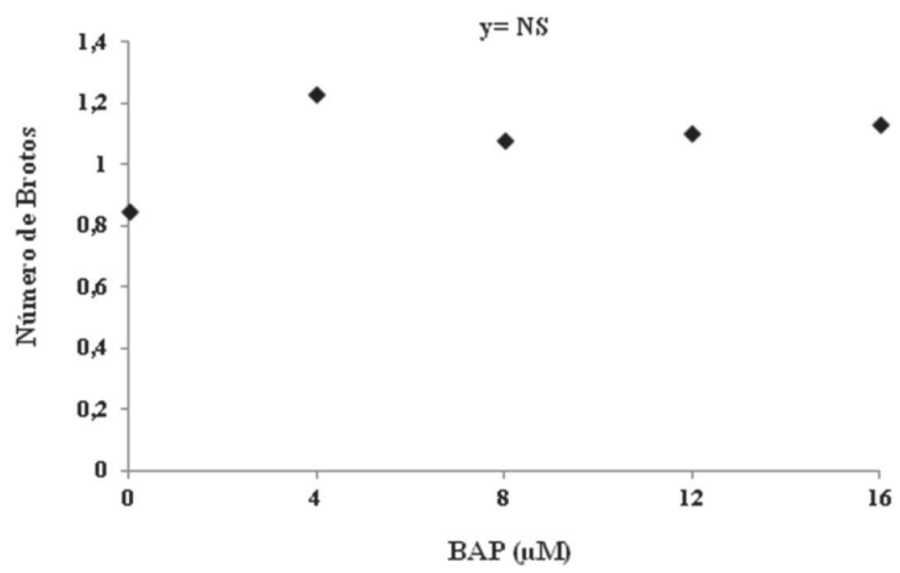

Figura 2. Número de brotos em função das concentrações de BAP em explantes de mulungu aos 30 dias de inoculados em meio de

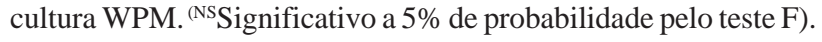


brotações múltiplas em ápices caulinares de erva-mate, a partir de embriões zigóticos, após três subcultivos em meio suplementado com $0,044 \mu \mathrm{M}$ de BAP.

$\mathrm{O}$ acréscimo de citocinina ao meio de cultura provavelmente acumulou-se nos ápices produtores de auxina dos explantes embriões zigóticos e plúmula, promovendo, assim, um balanço auxina/citocinina favorável ao crescimento vegetal, mantendo a dominância apical e impedindo o desenvolvimento das gemas laterais e adventícias, em explantes de mulungu. Segundo George et al. (2008), a obtenção de múltiplos brotos pode ser iniciada a partir de semente, principalmente em espécies lenhosas como mulungu, ocorrendo nódulos axilares ou brotações adventícias, em meio basal acrescido de citocinina, desde que seja dado o estímulo correto.

Ao se analisar o número de folhas, também foi observado efeito significativo da concentração de BAP e Tipo de explante isoladamente. Em função das concentrações de BAP (Figura 3), constatou-se um comportamento linear decrescente, obtendo-se a maior média na presença de 4,0 $\mu \mathrm{M}$ de BAP. Esse decréscimo do número de folhas pode ser um indicativo de fitotoxicidade do regulador de crescimento BAP (Grattapaglia \& Machado, 1988).

Em relação ao tipo de explante, verificou-se a maior média $(7,15)$ para a variável número de folhas, quando utilizado o embrião inteiro, valor significativamente superior aos obtidos para o explante plúmula $(2,35$ por explante), únicos explantes testados que apresentaram formação de folhas.

O comprimento da parte aérea foi influenciado pela interação BAP e tipo de explante. Em função do tipo de explante não foi possível o ajuste de uma equação significativa, com significado biológico para o explante plúmula (Figura 4). No entanto, para embrião inteiro, a equação que melhor se ajustou foi a quadrática descendente. Verificou-se redução do comprimento dos brotos, com o aumento das concentrações de BAP, obtendo-se o maior comprimento $(67,93 \mathrm{~mm})$ em meio isento de regulador de crescimento vegetal (Figura 3). Esse

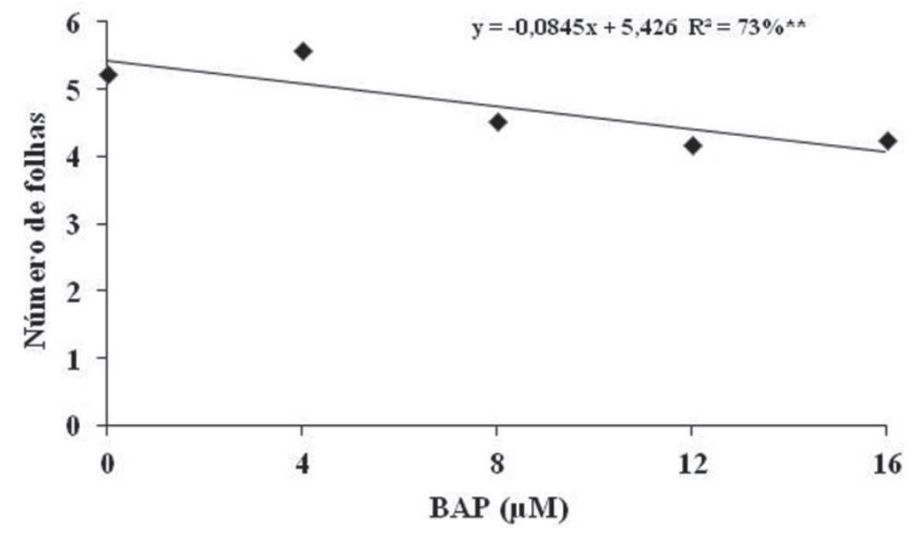

Figura 3. Número de folhas em função das concentrações de BAP em explantes de mulungu aos 30 dias de inoculados em meio de cultura WPM $\left({ }^{* *}\right.$ Significativo a $1 \%$ de probabilidade pelo teste F).

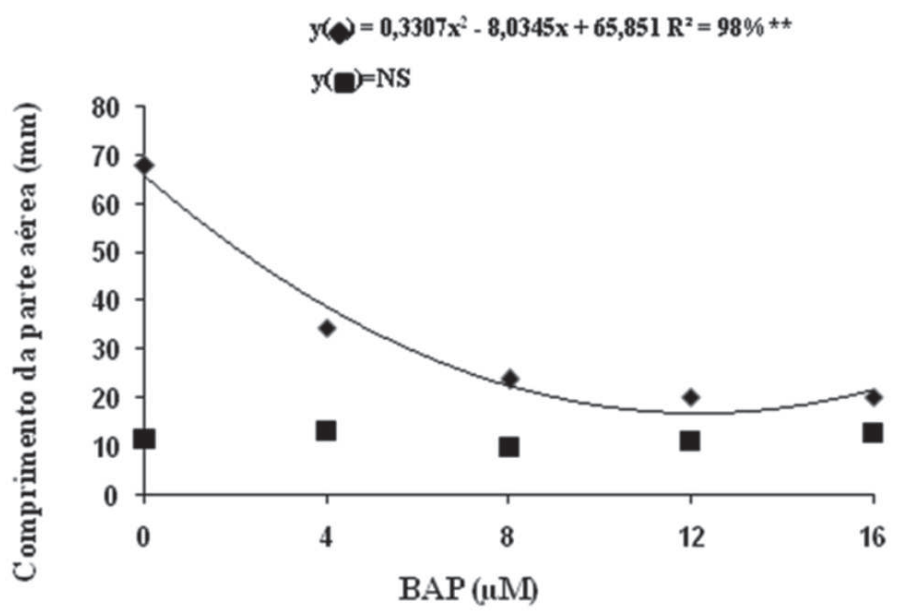

Figura 4. Comprimento da parte aérea obtido de explante de embriões zigóticos inteiro ( ) e plúmula ( $\square$ ) de mulungu em função dos níveis de BAP após 30 dias de inoculação em meio WPM ( ${ }^{* *}$ Significativo a $1 \%$ de probabilidade pelo teste F; ${ }^{\text {NS}}$ Significativo a $5 \%$ de probabilidade pelo teste $F$ ). 


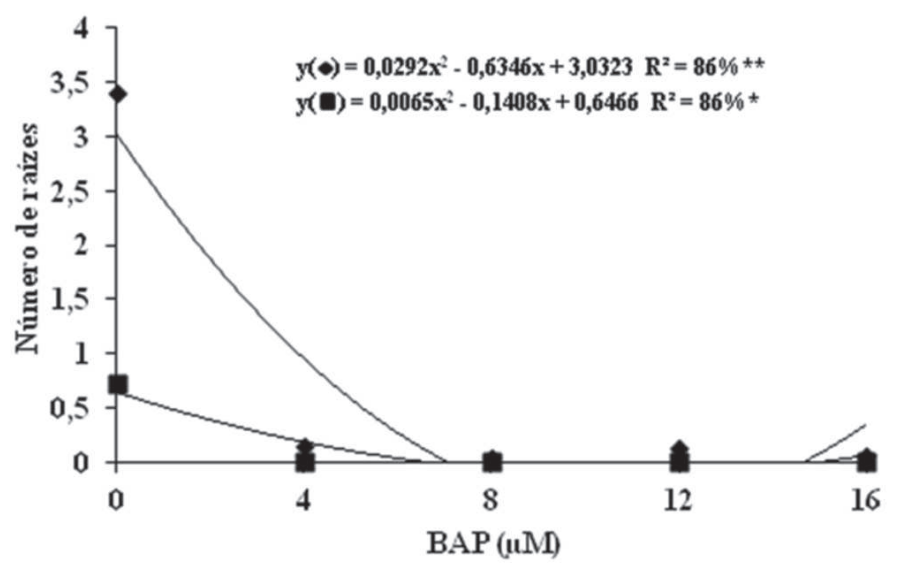

Figura 5. Números de raízes obtidos de explante de embriões zigóticos inteiro ( ) e plúmula ( $\square$ ) de mulungu em função dos níveis de BAP após 30 dias de inoculação em meio WPM $\left({ }^{* *}\right.$ Significativo a $1 \%$ de probabilidade pelo teste F; "Significativo a $5 \%$ de probabilidade pelo teste F).

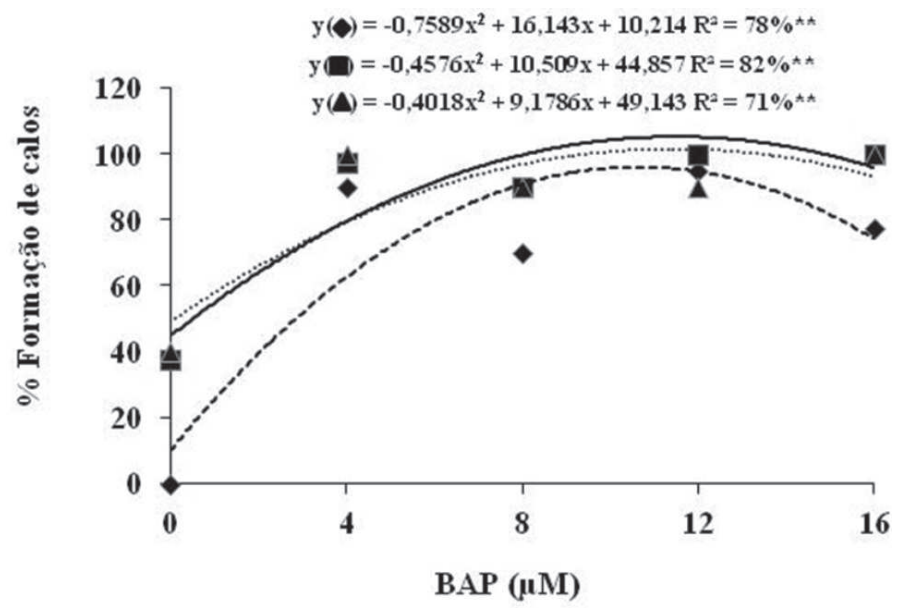

Figura 6. Formação de calos em função de BAPe ANA ( ) 0,0; ( $\mathbf{\square}$ )1,0; ( $\mathbf{\Delta}$ ) 2,0 ANA após 30 dias de inoculação em meio WPM $\left({ }^{*}\right.$ Significativo a $1 \%$ de probabilidade pelo teste $\left.\mathrm{F}\right)$.

resultado é corroborado por Benmahioul et al. (2009), que constataram melhor crescimento (26 e $25 \mathrm{~mm}$ ) da parte aérea de embriões isolados de pistache (Pistacia vera $\mathrm{L}$.), em meios sólidos ricos em nutrientes (DKW e MS) na ausência de regulador de crescimento vegetal.

De acordo com Costa \& Aloufa (2007), muitas vezes o acréscimo de reguladores de crescimento vegetal exógenos pode não ser benéfico, por causa dos teores indeterminados de hormônios endógenos do embrião.

A variável número de raízes foi influenciada pela interação BAP e tipo de explante. Para os explantes embrião inteiro e ápice plumular registrou-se comportamento quadrático descendente, em relação às concentrações de BAP (Figura 5). A formação de calo na base dos explantes, na presença de BAP, mesmo em concentrações baixas, provavelmente inibiu a formação de raízes. Comportamento semelhante foi reportado por Costa \& Aloufa (2007), no cultivo in vitro de embriões zigóticos maduros de tamareira (Phoenix dactylifera
L.), os quais observaram que apenas as plântulas oriundas do meio de cultura isento de regulador de crescimento apresentaram raízes primárias normais.

De acordo com Grattapaglia \& Machado (1998), a formação de calo na base dos explantes, em espécies lenhosas, pode estar associada a quantidades excessivas de auxinas e sacarose, comprometendo dessa forma o processo de rizogênese.

A interação BAP e ANA influenciou a variável percentagem de calos. Nos explantes região intermediária e radícula, foi observada a formação de calos, apresentando comportamento quadrático ascendente das concentrações de ANA, em relação às de BAP. A curva de resposta indicou que, na concentração 2,0 $\mu \mathrm{M}$ de ANA e $10,63 \mu \mathrm{M}$ de BAP, atingiu-se o valor máximo estimado $(96,06 \%)$ para a formação de calos (Figura 6). Os calos em todos os tratamentos apresentaram textura compacta e coloração branca, o que pode ser um indicativo de alta atividade auxínica (Termignoni, 2005). 
A formação de calos nos explantes região intermediária e radícula pode estar associada ao balanço auxina/ citocinina, favorecendo a formação de calos, bem como, a sensibilidade do tecido explantado, pois tecidos embrionários têm maior facilidade de expressar a totipotência, por serem jovens e ativos.

\section{CONCLUSÕES}

Maiores taxas de regeneração dos explantes plúmula e embrião zigótico foram obtidas em meio de cultura WPM, suplementado com $4 \mu \mathrm{M}$ de BAP.

$\mathrm{Na}$ ausência de regulador de crescimento foi verificada a maior média $(67,93 \mathrm{~mm})$ de comprimento da parte aérea dos brotos, a partir de embrião zigótico.

As regiões intermediárias e a radícula apresentam potencial morfogênico para formação de calos compactos, quando cultivadas em meio de cultura WPM, suplementado com 10,63 $\mu \mathrm{M}$ de BAP e 2,0 $\mu \mathrm{M}$ de ANA, que podem ser fonte de estudo para obtenção de brotos por via da organogênese indireta.

\section{AGRADECIMENTO}

Os autores agradecem à Universidade Estadual de Feira de Santana pelo aporte físico e, à FAPESB, pelo apoio financeiro na concessão de bolsas.

\section{REFERÊNCIAS}

Aasim M, Khawar KM \& Ozcan S (2009) In vitro micropropagation from plumular apices of turkish cowpea (Vigna unguiculata L.) cultivar Akkiz. Scientia Horticulturae, 122:468-471.

Bassan JS, Reiniger LRS, Rocha BHG, Severo CRP \& Flôres AV (2006) Oxidação fenólica, tipo de explante e meios de cultura no estabelecimento in vitro de canafístula (Peltophorum dubium (SPRENG.) TAUB.). Ciência Florestal, 16:381-390.

Benmahioul B, Kaid-Harche M, Dorion N \& Daguin F (2009) In vitro embryo germination and proliferation of pistachio (Pistacia vera L.). Scientia Horticulturae, 122:479-483.

Costa GM, Nepomuceno CF \& Santana JRF (2010) Propagação in vitro de Erythrina velutina. Ciência Rural, 40:1090-1096.

Costa NMS \& Aloufa MAI (2007) Desenvolvimento in vitro de embriões zigóticos de tamareira. Revista Ciência Agronômica, 38:276-279.

Dantas ACM, Moraes LKA, Pedrotti EL, Nodari RO \& Guerra MP(2002) Superação in vitro da dormência de embriões do porta-enxerto de macieira M9 (Malus pumilla Mill.). Revista Brasileira de Fruticultura, 24:10-14.

Ferreira DF (2011) Sisvar: a computer statistical analysis system. Ciência e Agrotecnologia, 35:1039-1042.

Handro W \& Floh EIS (1990) Aspectos básicos do controle da morfogênese in vitro. In: Torres AC \& Caldas LS. (Eds.). Técnicas e Aplicações da Cultura de Tecidos de Plantas. Brasília, ABCTP/ EMPRAPA-CNPH. p.203-212.

Hu CY \& Ferreira AG (1998) Cultura de embriões. In: Torres AC, Caldas LS \& Buso JA. (Eds.) Cultura de tecidos e transformação genética de plantas. Brasília, EMBRAPA-SPI/ EMBRAPA-CNPH. p.371-93.
George EF \& Debergh PC (2008) Micropropagation: Uses and Methods In: George EF, Hall MA \& Deklerk GJ (Ed.) Plant Propagation by Tissue Culture, v. 1 The Background. $3^{\mathrm{a} e d}$. Dordrecht, Springer. p.2964.

George EF \& Sherrington PD (1984) Plant propagation by tissue culture. Eversley, Exegetics. 709p.

Grattapaglia D \& Machado MA (1998) Micropropagação. In: Torres AC, Caldas LS \& Buso JA (Eds.) Cultura de tecidos e transformação genética de plantas. Brasília, CBAB/EMBRAPA. p.183-260.

Horbach MA, Bisognin DA, Kielse P, Quadros KM \& Fick TA (2012) Micropropagação de plântulas de erva-mate obtidas de embriões zigóticos. Ciência Rural, 41:113-119.

Lloyd G \& Mccown B (1980) Use of microculture for production and improvement of Rhododendron spp. HortScience, 15:415.

Pereira JES, Maciel TMS, Costa FHS \& Pereira MAA (2006) Germinação in vitro de embriões zigóticos de Murmuru (Astrocaryum ulei). Ciência e Agrotecnologia, 30:251-256.

Pinto DLP, Almeida AMR, Rêgo MM, Silva ML, Oliveira EJ \& Otoni WC (2012) Somatic embryogenesis from mature zygotic embryos of cmercial passionfruit (Passiflora edulis Sims) genotypes. Plant Cell Tissue Organ Culture, 107:521-530.

Queiroz LP (2009) Leguminosas da caatinga. Feira de Santana, UEFS. p.467.

Santana JRF, Paiva R, Pereira FD \& Oliveira LM (2008) Estímulo do comportamento fotoautotrófico durante o enraizamento in vitro de Annona glabra L. desenvolvimento do sistema radicular e da parte aérea. Ciência \& Agrotecnologia, 32:80-86.

Taiz L \& Zeiger E (2009) Fisiologia vegetal. $4^{\mathrm{a}}$ ed. Porto Alegre, Artmed. p.849.

Termignoni RR (2005) Cultura de Tecidos Vegetais. Porto Alegre, Editora da UFRGS. 182p.

Ulisses C, Albuquerque CC, Willadino L \& Camara TR (2011) Indução de embriões somáticos a partir de embriões zigóticos de Heliconia bihai (L.) L. cv. Lobster Claw Two. Revista Ceres, 58:537-541. 